\title{
Cihannüma
}

Tarih ve Coğrafya Araştırmaları Dergisi

Say1 VII/1 - Temmuz 2021, 203-213

Doi: $10.30517 /$ cibannuma.970841

\section{Marc Van De Mieroop, Philosophy Before the Greeks: The Pursuit of Truth in Ancient Babylonia, Princeton: Princeton University Press, 2016, 297 sayfa. ISBN: 978-0-691-17635-2.}

\section{Giriş}

Fransız düşünür Jacques Derrida Gramatoloji isimli önemli çalışmasında yazıyı ya da yazınsal iletileri söz merkezciliğin yerine ikame ederek yazının söz(lü) olana önceliğini ve üstünlüğünü göstermeye çalış1r. Ona göre yazı, sözün gücüyle görünür olmayan, baskılanan ve dişlanan şeyleri açık bir şekilde yayarak ona baskıın gelmiştir. Böylece şeyleri daha somut veya görünür kılmıştır. Bu görünürlüğün yaygınlaşması için okuma eyleminin devreye girmesi gerekmektedir. Yazı aracıllı̆ıyla metinleştirilenler ancak okuma ile birlikte bir anlam kazanır ve bu anlam her yeni okumada farklı bir yönünü ele verir. ${ }^{1}$ Bu bağlamda Alman felsefeci Hans-Georg Gadamer Hakikat ve Yöntem isimli iki ciltlik eserinde şeyleri (yazıll da olan) anlamlandırmaya çalışmanın aynı zamanda onları yorumlamak anlamına da geldiğini söyleyerek anlam çeşitliğine kavuşabilmek için belirli/belirlenmiş yöntemlerin sınanmasindan ve sinırlıliklarından kurtulmanın ya da en azından bunun dişında kalabilmenin önemine dikkat çeker. ${ }^{2}$ Yazılı olandan farklı anlamlar çıkarabilmek için onu farklı farklı yorumlamak gerekmektedir. Bu ise ancak kesin çizgilerle çerçevesi belirlenmiş metodolojik bir sinırlılıkla değil akışkan ve dikey-yatay genişlemeye olanak sağlayan bir yöntem bilgisi ile mümkündür. Bu yöntem elbet yazıya ve ondan elde edilecek anlamlara bağlantılıdır.

Son yıllarda Eski Mezopotamya'nın düşünce tarihiyle ilgili yapılan akademik çalışmalar genellikle karşısına çıkan şu üç bariyeri aşmaya çalışmaktadır. Bunlar, Avrupa merkezci (doğuya dair önyarg11) söylem, terminolojik determinizm ve modern bilimsel paradigmalardır. 20. yüzyllın son çeyreğine kadar Eski Mezopotamya'nın kültürel değerlerini konu edinen akademik çalışmalar onların "ilkel uygulamalarına ve şeylere dair zayıf akıl yürütme biçimlerine" göndermede bulunan yanlı "etik" yaklaşımların kıskacından büyük oranda kurtulamadı. Halbuki daha eksiksiz ve yansız bir tarih yazımı olanağı açısından Mezopotamyalılardan miras olarak kalan çok sayıda çivi yazılı tablet ve maddi kültür materyali ancak kendi gelenekleri, kültürel çevreleri ve dünya-yaşam olanakları açısından "emik" bir yaklaşımla (onların dünyayı veya şeyleri kendilerine göre kavrama biçimlerini öncellemenin gerekliliği anlamında) ele alınmalıydı. Kültürel değerlerin tarihselliğini etraflıca anlayabilmek ve daha doğru bir zemine oturtabilmek için mantıkl1mantıksız, ilkel-gelişmiş ve mitolojik-bilimsel gibi kavramsal ayrımlann cazibesine kapılmadan yalnızca var olan şeylerin kendindeki bilgisini açı̆̆a çıkarmak adına “içeriden” bir yaklaşım ve kavrayış pratiği de gerekmektedir.

1 Jacques Derrida, Gramatoloji, (Çeviren: İsmet Birkan), Ankara: Bilgesu Yayıncılık, 2011.

2 Hans-Georg Gadamer, Hakikat ve Yöntem, (Çevirenler: Hüsamettin Arslan-İsmail Yavuzcan), Cilt I, İstanbul: Paradigma Yayınlar1, 2008. 


\section{Gökhan Kăgnucı}

\section{Felsefi Düşünce Biçimi}

Marc Van De Mieroop'un Philosophy Before the Greeks (Antik Yunanlilardan Önce Felsefe) başlıklı çalışması Eski Mezopotamyalıların şeyleri (bilgiyle) kavramalarının akıl yürütme biçimlerini ele alması açısından önemli bir çalışmadır. Yayınlanma tarihi üzerinden beş yil gibi bir süre geçmesine rağmen Eski Mezopotamya tarihi ile felsefe, düşünce ve kültür tarihi gibi alanlar açısından ülkemizde gereken önemin pek fazla verilmediği anlaşılan ${ }^{3}$ bu kitap beş kısım dokuz bölümden oluşmaktadır. Bu eser temelde tarihte ilk olarak çok büyük oranda antik Yunanlılara atfedilen (ya da onlarla başlatılan) felsefi ve bilimsel düşünce pratiklerinin aslında onlardan yüzyıllar öncesinde Mezopotamyalılar tarafindan, belirli bir okuryazar çevreyle sınırlı kalmakla birlikte, 1srarla ve yoğun bir şekilde sürdürülmüş olduğunu kanıtlamaya çalışır.

Bu çalışma ele alınan konuya dair bir “acaba mi” sorusunu gündeme taşıma niyetinde değildir. Kitap, Mezopotamyalılarda bir felsefe anlayışının ve uygulamalarının "kesinlikle" var olduğunu kanıtlarıyla göstermeyi amaçlar. Kitabın yazarı Mieroop'un antik Yunanlılardan önce var olduğunu öne sürdüğü düşün/me/ce ile teorik bilgi üretme arasındaki ilişkisel alandaki akıl yürütme faaliyetlerini "felsefe" olarak tanımlamış olması, (bir bilgelik sevgisi veya bilgi aşkı ediminin tarihte ilk olarak antik Yunanlılarla ortaya çıktığının tartışmasız kabulü, felsefe yapmanın onlarla özdeşleştirilmesi ve kelimenin içerdiği [felsefenin] uğraş1 alanının çoğu zaman bir terminoloji sorununa indirgenerek/ona bağlı kılınarak tanımlanmak istenmesi gibi nedenlerden ötürü) öncelikli olarak alan içinden (Asur bilim) birtakım eleştiriler almıştır. $\mathrm{Bu}$ eleştiriler genellikle Mieroop'un Mezopotamyalıların yazı merkezli anlamı ve yorumu öncelleyen uğraşı alanını ve biçimini var olan bir "felsefe (geleneği)" içerisinde değerlendirmek istemesi üzerine yoğunlaşmıştır. Ancak hemen ifade edilmelidir ki, bu eleştirilerin hiçbirisi kitabın temelini oluşturan Mezopotamyalıların yazıyla/yazı üzerinden düşünme pratiklerinin, söz gelimi çivi yazılı metinler üzerindeki derleme ve kopyalama çalışmalarının epistemolojik veya düşünsel kaygılarla ilgili olduğu iddiasının karşısında değildir. Eleştiri daha ziyade Mezopotamya tarzı entelektüel bilgi üretimi biçiminin antik Yunanlılarla özdeşleşen tanımlanma biçimiyle (philosophia) ve ona içkin olan bir bilme biçiminin analitik ve sistematik düşünme yöntemiyle ne kadar uygunluk arz etmiş olabileceği üzerinedir. Zira bir felsefeden bahsedilecekse bu ilk olarak antik Yunanlılarla başlatılmalıydı. Örneğin Mieroop'un Mezopotamyalılarda bir felsefe geleneğinin var olduğu iddiasına temkinli bir şekilde yaklaşan Yale

3 Kitap ile ilgili Türkçe olarak yalnızca iki değerlendirme yazısı tespit edebildim. Her iki değerlendirme de eski Yakındoğu tarihi alanında uzman olmayanlar tarafindan kaleme alınmıştır. Anlaşılan bu kitap ülkemizde Asur bilim ya da eski çağ tarihçiliği camiasından daha ziyade düşünce tarihi çalışanların daha fazla ilgisini çekmiştir. İlgili yazılar için bakınız: İhsan Fazlığlu, "Greklerden Önce Felsefe: Kadim Babil'de Hakikat Arayıșı", Arka Kapak Dergisi 18, 2017, s. 16; Merve Nur Yllmaz, "Marc Van De Mieroop. Babylonian Philosophy: Philosophy Before the Greeks: The Pursuit of Truth in Ancient Babylonia", Divan: Disiplinlerarası Callsmalar Dergisi 23/44, 2018-1, ss. 169-174. 
ekolünün önde gelen Asur bilimcisi Eckart Frahm’a göre Mezopotamyalı kâtiplerin ve bilginlerin bilgi üretim faaliyetleri filozofa (philosophos) has bir bilgi talep biçiminin, yaklaşımının ve icraatının kapsama alanına tam olarak girmez. Her ne kadar özellikle MÖ 1. binyılda eğitimli çevrelere mensup olan kimselerin bilgi üretim biçimleri ve var olan yazılı bilgi üzerindeki düşünme süreçleri birçoklarının yaptığı gibi mitolojik bir anlatı formunun ve zihniyetinin (mitopoetik) içeriğine ve yapısına indirgen(e)mese de bu tam anlamıyla bir felsefe olarak değerlendirilemez. Doğaya ya da doğal şeylere dair soruşturma biçimleri onları anlamak/anlamlandırmak amacından tamamen bağımsız değildi. Diğer yandan bilgi üretiminin bilimsel ve bilgince bir tarafı olduğu da göz ardı edilemezdi. Bundan dolayı Frahm’in önerisi bu düşünsel faaliyetleri felsefe olarak değil, ilmi nitelikteki uğraşılar olarak değerlendirmenin daha doğru olacağ1 yönündedir. ${ }^{4}$ Bir diğer önemli Asur bilimci Jay Crisostomo da benzer bir şekilde Mezopotamyalı okur-yazarların sıklıkla ilgilendiği farklı temalar ve içeriklerden oluşan başta liste hazırlama pratiklerinin, çivi yazısı aracılığıyla şeyleri kavrama düşüncesinin, çivi yazısının anlam-yorum çeşitliliğine olanak sağlama potansiyelinin, bilgi aktarımının geleneksel rolünün, hermeneutik çabaların, metinlerin içeriklerine ve yapılarına dair benzerliklerin, çok dilliliğin önemsenmesinin ve bir yorum tekniği olarak çeviri faaliyetlerinin bir felsefe edimiyle ilişkilendirilmesinden ziyade bu tür uğraşıların bilimsel-ilmi ilgiler, çabalar ve kaygılarla ilgili olduğunu düşünmektedir. ${ }^{5}$ Benzer eleştirileri çoğaltmak mümkün ancak anlaşılan bu konudaki temel tartışma Mezopotamya usulü entelektüel bilgi üretiminin ne türden bir faaliyet alanına tekabül etmiş olduğu üzerinedir. Bu türden bir üretiminin ve düşünce biçiminin felsefe yapmaktaki rolü (varsa?) ile onun (var olan!) bilimsel ve ilmi misyonu açısından bir kıymeti var mıydı? Mezopotamyalılar için (yazılı) bilginin, muhtemel olan ile gerçek, mahiyet ile öz, bütün ile parça ve ayrım ile benzerlik arasında salınan bir sarkaç olduğu düşünülebilir.

Mezopotamyalılarda bir felsefe geleneği var miydı, yoksa onların Mieroop'un da felsefi bir uğraş olarak değerlendirdiği epistemolojik çabaları, Mezopotamyalıların doğaya dair imgesel düşünceyi kavramlaştırma sorunu yaşadıklarını ileri süren diğer Asur bilimciler nazarında analitik ve sistematik düşünce biçimlerinin zayıf olduğu salt bilimsel-ilmi ya da eğitsel faaliyetler miydi? Mieroop'a göre felsefi bir düşüncenin varlığ1 kesindi. Özellikle yazı merkezli/yazı üzerinden ilerleyen bir akıl yürütme biçimi ve süreci kesinlikle felsefi bir edimle ilgiliydi. ${ }^{6}$ Ona göre belirli bir kavramsal tanımlama biçimine bağlı kılınmadan Mezopotamyalıların birtakım ilkelerle (her

4 Eckart Frahm, "The Perils of Omnisignificance: Language and Reason in Mesopotamian Hermeneutics", Journal of Ancient Near Eastern History 5/1-2, 2018, s. 19.

5 Jay Crisostomo, "Language, Translation, and Commentary in Cuneiform Scribal Practice", Journal of Ancient Near Eastern History 5/1-2, 2018, s. 42.

6 Mieroop bu türden eleștirilere cevap niteliğinde kaleme aldığı bir makalesinde bu yöndeki kanıtlarını 6 tez halinde tekrardan düzenlemiştir. Bakınız: Marc Van De Mieroop, "Theses on Babylonian Philosophy”, Journal of Ancient Near Eastern History 5/1-2, 2018, ss. 15-39. Bu makalenin Türkçe çevirisi için bakınız: Gökhan Kağnıcı, "Babil Felsefesi Üzerine Tezler", Cihannüma: Tarih ve Coğrafya Arasttrmalar Dergisi VI/2, 2020, ss. 231-258. 


\section{Gökhan Kağnucı}

zaman işleyen ve sınanabilen dört dörtlük ilkesel bir tutarlilıtan bahsedilemese de) bilgi üzerinden bir anlam arayışı ve inşası ile bilgiyi yorumlama faaliyetlerinin kendilerine has epistemolojik bir gelenekle ilgili olduğu kesindir. Mieroop kitapta bu çabalara ve uygulamalara dair iki temel şey üzerinde durur. Bunlardan ilki hakikatin bilgisine (?) ulaşmada çivi yazısının rolü, diğeri ise bilimsel listelerin kendilerine özgü olan Babil ${ }^{7}$ felsefesini görünür kılmadaki önemidir.

\section{Philosophy Before the Greeks}

Kitabın ilk bölümü Mezopotamyalıların "kozmogoni” bilgisini "kozmolojik" bir alanın bilgisi haline getirme çabalarını evrenin-insanın yaratılış anlatıları üzerinden analiz eder. Orijinal halinin MÖ 2. binyılın ilk yarısına tarihlendirildiği Babil Yaradılış Destanı olarak bilinen Enüma elis'te özellikle Babil'in baş tanrısı Marduk'un elli isminin filolojik, semantik ve hermeneutik analizleri, bilgi üzerine düşünmenin onlara has farklı bir düşünce sistemi ve modeli içerdiğini göstermesi açısından ele alınmıştır. Örneğin tanrı Marduk'un otuz altıncı ismi olan ve beş farklı çivi yazısı işaretiyle yazılan "lugalabdubur"' ifadesi analiz edildiğinde görülecektir ki (tanrının diğer isimlerinde olduğu gibi), Sumerce her bir işaretin $\left(\mathrm{lu}_{2} / \mathrm{gal}+\mathrm{ab}_{2}+\mathrm{du}_{10}+\mathrm{bur}_{3}\right)$ farkl1 okunuşları, ayrı birer anlamı, eş sesli, eşanlamlı ve ayrıca farklı dildeki (Akadca) karşılıkları söz konusudur. Dolayısıyla tek bir ismin yazılışı bu ismi oluşturan işaretlerin piktografik, ideografik, logografik ve hecesel görünüşlerinden, karşılıklarından, değerlerinden ve anlamlarından haberdar olmakla mümkündür ve ancak işaretlerin ve onların anlamlarının çok yönlü ve katmanlı bir analizi bu farkındalığı anlamaya yardımcı olabilmektedir. Mezopotamyalı bilginler bu konularla o kadar fazla ilgiliydiler ki, söz gelimi bin y1l öncesinin kanonik metinlerindeki katmanlı bilgiyi anlamak ve kavramak için onun üzerinde titizlikle çalışmış olmalılard1. Örneğin MÖ 1. binyıla tarihlendirilen "yorum metinlerinde" (kommentarlar) tanrı Marduk'a atfedilen söz konusu isimler birtakım hermeneutik tekniklerle hece hece analiz edilmiş, filolojik bir yapı sökümüne uğratılarak onlara anlamsal bir açıklık getirilmeye çalışılmıştır (ss. 7-9).

Aslında Mieroop kitabına evrenin ve insanın yaratılışını ele alan mitolojik bir anlatıyla başlayarak bu türden anlatılarla Babillilerin evren-kosmos yapısına dair bilgilerinin sınırlarını ve boyutlarını göstermeyi amaçlamamıştır. $\mathrm{O}$, bu insanların doğada var olan şeyleri sadece mitolojiler aracılı̆̆ıyla anlamlandırabilecekleri ya da kavrayabilecekleri yönündeki iddiaları eleştirerek ${ }^{9}$ mitolojilerin toplumsalliğının yerine daha başka bir hususa dikkat çeker. Şöyle ki, Mezopotamyalılar en temel

7 Mieroop, kitabının başlığında Mezopotamya kelimesi yerine Babil’i kullanmayı tercih etmiştir. Kitap boyunca Babil, bir dönemi, șehri ya da devleti tanımlamaktan ziyade coğrafi bir alanı imlemektedir. Babil, kuzeydeki Babil şehrinden güneydeki Basra körfezine kadarki Dicle ve Fırat nehri arasında kalan Güney Mezopotamya’nın kültürel sahasını içermektedir.

8 Muhtemel anlamı şu şekildeydi: “(tanrı) Tiamat'ın hilelerini engelleyen kral (Marduk), onun (Tiamat) ön ve arka taraflardan sağlamca desteklenmiş silahlarını yok etti”. Parantez içleri şahsıma aittir.

9 Marc Van De Mieroop, “Theses on Babylonian Philosophy”, s. 23. 
mitolojik anlatılarında bile yazının (çivi yazısının) bilme, anlama ve yorumlama pratiklerindeki gücünden ve etkisinden ziyadesiyle faydalanmışlardır. Bu türden anlatılarda bile çivi yazısının şeyleri düzenlemedeki dinamik yapısının ön plana çıkartılması çabası görülür. Çivi yazısı, yapısı gereği çok geniş bir anlam çeşitliğini mümkün kılabildiği için, yazıyla üretilen bilgiyi yapısal, fonetik ve semantik içeriği üzerinden çözümlemeye çalışmak bir bilme ve anlama çabasıyla yakından ilgiliydi (s. 9). Bu türden çabalar Mieroop'e göre bir hakikat keşfi ya da hakikate ulaşmanın bir yoludur. Ancak bana kalırsa çivi yazısı görünüşü ve içerdiği zengin anlam derinliğine rağmen ne bir hakikat cevheri içerir ne de sonu özsel kavrayışla sonuçlanacak bir yol sunabilirdi. Yazıdan kaynaklanan çoklu anlam çeşitliliği ve buna bağlı olarak değişkenlik arz eden bilginin, sürekli devam eden bir çabaya tabi olması nedeniyle bu entelektüel faaliyetlerin öncelikli amacı hakiki olanı bularak kendini sabitlemek değildi. Amaç, durmadan/sürekli, şeyleri (daha iyi) anlamaya çalışmaktı. Bundan dolayı bu faaliyetler nihayetinde bir öze ya da özsel olana kavuşmayı arzulayan teleolojik bir düşünce biçiminin varlığını kesin olarak kanıtlayamaz. Diğer bir deyişle bilgi üretimi veya bilgi üzerine düşünme, bilginin kendisinde var olan bir öze ulaşmaya çalışmıyordu. Mezopotamyalı bilginler çivi yazısını bilgi üretmenin ilham kaynakları olarak gördüler. Zira Mezopotamyalıların düşünce biçimleri temelde yazıya içkin kılındığı için yazıyla ve yazı üzerinden bir düşünce modeli tam da sürekliliğinden-kesintisizliğinden dolayı hakiki olana ulaşmayı vaat edemezdi. Mezopotamya usulü bilme uğraşısının “arayışı” düşünce dünyasını zenginleştirmek için daha fazla bilgi edinmeye odaklanmıştı. Önemli olan yazarak bilgi üretmekti. Metinlerin kim tarafından kaleme alındığının çok büyük bir oranda önemi yoktu. Bu durum binlerce yıllık bir yazılı geleneğin ürünleri olan yüzbinlerce çivi yazılı metnin yazarlarının (kişi ya da kurum ismi) bilinmemesi/belirtilmemesinden de anlaşılabilmektedir.

Eski Mezopotamyalıların çivi yazılı tabletlerinin çok büyük bir kısmında yazar adına rastlanmaz. Onların yazarlık anlayışı özgün fikirlerin, kişisel yorumların ve eleştirel bakış açılarının yoğunluk arz ettiği yeni metinler inşa etmekle değil, genellikle var olan (kadim) metinlerin korunmas1, aktarılması, düzenlenmesi, derlenmesi ve kopyalanması ile ilgiliydi. Ancak elbette ki yazılı olanın bilgisinin geleneksel yollarla nesillerden nesillere yazılı olarak aktarılma sürecinde yorum tekniklerinin, filolojik çözümlemelerin veya Sumer ve Akad dilinin gramer yapısının detay bilgisine sahip bilginler/alimler sinıfinın entelektüel müdahaleleri her zaman özgün yönler içerebilmekteydi. Eski Mezopotamya'da (modern anlamda) yazarlık hiçbir zaman, bir tanımlanma biçimi olarak, metinlerin ilk var edicileri kavramılla sınırlandırılmamıştır (ss. 20-26).

Kitabın 2-7. bölümleri sözcük listelerine, kehanet serilerine ve kanunnamelere (genellikle Hammurabi Kanunnamesi olarak bilinen metne) odaklanmıştır. İlk örneklerine MÖ 4. binyllın sonundan itibaren rastlanan kimi örneklerinde on binlerce kelimenin sıralandığı (bazen tematik bir içerikle) Sumerce ve Akadca sözcük listelerinin, MÖ 1. binyılın sonlarına kadar geleneksel bilginin üretildiği, öğrenildiği ve aktarıldığ1 çevrelerde kullanılmaya devam edildiği bilinmektedir. Yalnızca eğitim- 


\section{Gökhan Kağnucı}

öğretim amacına hizmet etmeyen aynı zamanda bilimsel-düşünsel faaliyetlerle de ilgili olan bu listeler, temelde somut ya da soyut şeylerin listeleme mantığıla kavranabilme olanaklarını içermedeki işlevleri yüzünden oldukça önemsenmiştir. Sözcük listeleri Mezopotamyalıların dünyayı anlamlandırma ve algılama çabalarını yansıtmaktaydı. Bundan dolayı sadece fiziksel bir gerçeklikle ilgili değillerdi. Listelerdeki kelimeler fonetik ve filolojik açılardan anlamsız-mantıksız olabilir ya da gündelik yaşam pratikleri açısından bir değeri ve yeri olmayabilirdi. Zira önemli olan yazılı bir gerçeklik inşasıydı. Listelerdeki kelimelerin seçimi, dizilimi, diğer kelimelerle ilişkisi, çivi yazılı işaretlerin şekil, fonetik ve hece benzerlikleri kendi içerisinde (söz konusu listeye özgü olan) tutarlı bir mantık arz etmekteydi. Örneğin tek bir Sumerce logogramın birden farklı Sumerce hece değeri veya Akadca karşıllı̆1 bulunabilmekteydi. Ya da farklı işaretler tek bir anlama gelecek şekilde okunabilmekteydi. Hatta bazı işaretlerin yüzlerce farklı okuma biçimi dolayısıyla anlamı bulunabilmekteydi. Örneğin Sumerce "bar" işaretinin 200 civarı karş1lı̆̆1 bulunabilmekteydi. Bir işaret farklı iki okunuşa sahip olduğunda ortaya bambaşka bir anlam çıkabilirdi. Örneğin aynı çivi yazısı işareti hem "dünyanın kralı" ( hem de "yabancı kral” (šarru aḩû) olarak yorumlanabilirdi. Çünkü Sumerce "šúu" işareti Akadca hem kiššatu hem de aḩû olarak okunabilmekteydi. ${ }^{10}$ Kitapta da ele alınan benzer bir başka örnek Sumerce "TUG," olarak okunan logogram ile ilgilidir. Bu logogramın şimdiye kadar dört farklı hece değeri karşılığı tespit edilmiştir (mu$\mathrm{u}_{4}+\mathrm{tu}-\mathrm{u}_{4}+$ nam $+\mathrm{u}_{4}$-mu-uš). Bu hecesel okunuşlarının her birinin ayr1 ayr1 Akadca karş1lıkları bulunmaktadır. Hatta bir tanesinin (umuš) iki Akadca karşılığ1 (țemu ve milkum) bulunmaktadır ve bu iki Akadca kelimenin anlamları da birbirlerinden farklıdır (ilki, "akıl"; ikincisi "nasihat") (s. 44). Hiç kuşkusuz bu durumun ilk etapta bir anlaşılmazlığa veya karışıklığa yol açabileceği düşünülebilir, ancak Babil epistemolojisi, yöntemi ve yorum bilgisi bu durumların üstesinden kolayca gelinecek bir formasyona sahipti. Sözcük listelerindeki kelimelerin somut dünyada karş1lı̆̆1 olmayan fiziksel gerçek dişılığ1, sözde anlamsızlığı, mantıksızlığ1 ve belki de keyfiliği temelde teorik bir akıl yürütme biçimiyle ilgiliydi ve teorik bilginin alansal sorumluluğunu taşımaktaydı. Önemli olan listeleme mantı̆̆1 ya da sözcük listelerinin iç mantığı açısından belirli ilkelere dayalı (kelimelerin tematik, semantik, fonetik, analojik ve çivi yazılı işaretlerin görünüşlerine, benzerliklerine, eşanlamlı ve eş sesli özelliklerine göre dizilimleri) bir tutarlılık gösterilmesiydi (ss. 35-87). Sözcük listelerinin hazırlanmasıyla son tahlilde amaçlanan şey söz gelimi "mor renkli” bir "limangonun" (limon+mango) sikilınca "turuncu renkte tatlı bir bal" akitmasinin olasılığını kaydederek bunu yazılı bir sistem üzerinden düşünmekti.

Babil düşünce sisteminin biçimlerine nüfus edebilmeye olanak sağlayan ikinci kaynak grubu kehanet serileriydi. Gelecekte gerçekleşmesi muhtemel olaylarla görünür ve gözlemlenebilir şeyler arasında ilişki kurmaya olanak sağlayan bu seriler Mezopotamyalıların yorum bilgilerini ve tekniklerini göstermesi açısından oldukça

10 Eckart Frahm, "The Perils of Omnisignificance: Language and Reason in Mesopotamian Hermeneutics", ss. 13-14. 
önemliydi. Kehanet mantığ1 her ne kadar Mieroop nazarında evrene dair şeyleri analiz etmenin, çözmenin ve içerisindeki özü keşfetmenin bir başarısı olarak görülse de kehanetler aslında bir tür poligon alanlarıydı. Her ne kadar bu türden serilerdeki ana cümle-yan cümle ya da neden-sonuç cümleleri arasındaki ilişki bir tür akıl yürütme pratiğinin ("X öyleyse, Y şöyle olacaktır") yazılı dinamizmine işaret etse de öze içkin olanı elde etme garantisi hiçbir zaman sağla(ya)mazdı. Kehanet serileri sanılanın aksine çoğunlukla doğada gerçekleşenin ve yaşanılan çevrede olup bitenin gözlemlerinin kayıtlarından oluşmuyordu (s. 101). Doğa elbette ki geleceğe dair bazı öngörülerde bulunabilmenin bazı şifrelerini içermekteydi. Ancak bunun birtakım yöntemlere bağlı kalınarak deşifre edilmesi gerekmekteydi. İşte bu seriler bu şifrelerin deşifre edilmesinin olasılıklarının sınandığı yerlerdi. Kehanet serileri tıpkı sözcük listeleri gibi fiziksel bir gerçeklik yerine yazılı bir gerçekliği öncellemekteydi. Yazılı kehanetler kullandığı dil, içerdiği ifade biçimleri ve yapısal benzerlikler açısından teorik olasılıklar içerir ve imkânsız olanın potansiyelini sınardı. Anlamı ve yorumu devreye sokmayı teşvik ederdi. Kehanet serileri söz gelimi “eğer bir yere oturursan, oradan kalkamayacaksın” türünden bir gelecek öngörüsünün "iktidar tatlıdır, kolay kolay bırakılmaz" şeklindeki bir mesaj1-uyarıyı örtük anlamda ilettiği türden metinlerdi. Ancak bu ilişki yalnızca kültürlü çevrelere has olan yorum bilgisinden ve tekniğinden haberdar olanlar ya da bu konuda eğitimli olanlar tarafindan kurulabilirdi.

Kitapta ele alınan üçüncü metin türü ise yasa maddeleriydi. Mieroop kitabında

k1saca bütün Mezopotamya kanunlarından ve onların tarihsel süreçlerinden bahsetmekle birlikte daha ziyade Eski Babil kralı Hammurabi'nin kanunnamesini mercek altına almıştır. Örneğin 6. bölüm bütünüyle yasa maddelerinin içeriklerinden ve yapisindan bahsederek Hammurabi kanunnamesinin kopyalanma ve sonraki dönemlere etkisinin tarihini ele alır. 7. bölümde ise kanunnamenin Babil epistemolojisindeki yeri tartışılmıştır. O, ilk bakışta hukukun alanıyla ilişkilendirilen bu Babil yasa kodeksinin aslında arkasındaki bilimsel-ilmi ilkelerin ve yoruma dayalı tekniklerin sözcük listeleri ve kehanet serilerindekine en çok benzeyen metin olduğunu ileri sürmüştür. Tıpkı onlardaki gibi kanunnamenin de büyük oranda gerçek vakalarla ilgilenmekten daha ziyade teorik bir felsefi içeriğe sahip olduğunu düşünmüştür. Ona göre kanunnamede sözü geçen suçlar ve onlara verilen cezalar öncelikli olarak toplumsal hayatı adaletle düzenlemek anlayışının deneyimlenmiş hukuki pratiklerine karşılık gelmemektedir (ss. 163-165). T1pk1 sözcük listeleri ve kehanet serilerini düzenleyen kâtipler gibi kanunname üzerinde çalışan Babilli kâtiplerin de yapmaya çalıştı̆̆1 şey temelde bilginin anlam yelpazesini genişletmek ve teorik bir katmanlaşmanın olasılıklarını aramak ve sınamaktı. Bunu da diğer iki metin türüne dayalı düşünce ve kavrama biçimlerine benzer bir şekilde gerçekleştirmişlerdi (ss. 172-173). Ayrica Mieroop, Hammurabi kanunnamesinin hukuki ve siyasi bir değer taşımaktan ya da kralın adaletini ön plana çıkaran hukuki bir metin olmaktan daha ziyade temelde kralın bilgeliğini gösteren epistemolojik bir değer ihtiva ettiğini ileri sürer. Bu iddiasına birtakım gerekçeler sunar. Bunlardan ilki kanunnamenin içerisindeki birtakım pasajların sonraki dönemlere (bin yıl sonrası bile) tarihlendirilen 


\section{Gökhan Kağnucı}

farklı metinlerde yer almış olmasıdır. Bu kopyalama faaliyetini metnin içeriğinin tarihselliği konusu açısından değerlendirir. Ayrıca kanunnamenin giriş bölümünde geçen Akadca kittum ve mǐsarum kelimelerinin anlamı üzerinden yürüttügü bir tartışmayla Hammurabi kanunnamesinin felsefi bir değeri olduğu iddiasını sağlamlaştırmak ister. Söz konusu ifadenin genellikle kralın doğruluğu ve adaletli oluşu ile ilişkilendirilmesinin eksik bir etimolojik bakış olduğunu ileri sürerek özellikle kittum kelimesinin anlamlarından bir tanesi olan "hakikatin” çoğu zaman göz ardı edildiği üzerinde durur. Ona göre bu kelime yalnızca kralın adalet anlayışına vurgu yapmaz aynı zamanda bu anlayışın bir parçasını oluşturduğu daha yüce/aşkın bir duruma, temsilcisi ya da icracısı olduğu bir hakikat alanına göndermede bulunur. Ayrıca bu durum kralın bilgeliğine de göndermede bulunur. O, Eski Babil kralı Hammurabi'nin daha sonraki dönemlerin Mezopotamya yazıll geleneğindeki ününün de onun bu bilgeliğinden kaynaklandığını ifade etmiştir (ss. 174-175). Açıkçası bu konu tartışmaya oldukça açıktır. Bana kalırsa Mieroop suç ve ceza dikotomisi üzerinden inşa edilen bir metnin alanını hukuktan felsefeye ikame etme konusunu çok ikna edici bir şekilde temellendir(e)memiştir. Zira Hammurabi'nin şöhretinin onun bilgeliğinden kaynakladığı ya da kanunnamenin öncelikli amacının bu bilgeliğin bir kanıtı olarak sunulduğu yönündeki yorumları teyit edecek hatta güçlendirecek çivi yazılı kanıtlar oldukça az ve dolaylıdır. Hammurabi'nin MÖ 2. ve 1. binyıla tarihlendirilen Mezopotamya'nın siyasi, dini ve edebi çivi yazılı metinlerinde adı siklıkla anılmasına rağmen ${ }^{11}$ bu metinlerin hiçbirinde kralın bilgeliğine ya da bilgece işlerine doğrudan bir atıf yoktur. Kitapta kralın bilgeliğine kanıt olarak sunulan göz hastalıklarıyla ilgili bir tedavi metninin (BAM 159 iv 16'-22') içinde geçen "Hammurabi’nin göz merhemi" (teqit igiII.MEŠ $\check{s} a$ mHammurapi) ifadesi ise kralın tip konusundaki bilgisinin üstünlüğüne, sınırlarına ve içeriğine dair herhangi bir detay sunmaktan uzaktır. ${ }^{12}$ Kanunnamenin içerisindeki bazı içeriklerin yüzyıllarca kopyalanması açısından kurulan bir şöhret ilişkisi/biçimi de dahil Hammurabi'nin ünü çok büyük ihtimalle ve genellikle kabul edildiği üzere, kanunnamedeki yasa maddeleri gerçekten yaşanmış vakalarla doğrudan ilişkili olsun ya da olmasın ${ }^{13}$ veya hukuki bir içerik üzerinden kurulmuş bilimsel bir doğası bulunsun ya da bulunmasın, temelde adil kral vasfindan kaynaklanmaktaydi. Bana kalırsa Hammurabi Kanunnamesi yenilemeli tekrarın, (birtakım benzerlikler açısından birbirleriyle ilgili yasa maddelerinin oluşturulmasi) görünüşün ve temsilin (Hammurabi steli ve içeriğindeki yasa kodeksi) bir değer (adalet, eşitlik, güven, meşruiyet vs) olarak sunulabilmesindeki rolünün olasılıklarının sınandı̆̆ı bir metindi.

11 Marc Van De Mieroop, King Hammurabi of Babylon: A Biography, Blackwell: Oxford, 2005, ss. 122134.

12 Bu konuda bakınız: Marc Van De Mieroop, Philosophy Before the Greeks: The Pursuit of Truth in Ancient Babylonia, s. 176; Marc Van De Mieroop, King Hammurabi of Babylon: A Biography, s. 131; JoAnn Scurlock, Sourcebook for Ancient Mesopotamian Medicine, Atlanta: SBL Press, 2014, ss. 364-367.

13 Kitapta söz konusu edilen listeleme mantığıyla düzenlenmiş bütün metin türlerinde bu tarz bir ilişkinin (yazılı kaydın gündelik/pratik karşılığına bir şekilde tekabül etmesi anlamında) olmadığı bütünüyle ileri sürülemez. 
Kitabın beşinci kısmı ise iki bölüm halinde ele alınmıştır. Bunlardan ilki (8. bölüm) Babil epistemolojisinin tarihinden bahseder. Bu tür entelektüel faaliyetler MÖ 2. binden Helenistik dönemin sonuna kadar uzanmaktaydı. Anlaşılan bilgi üretimin süreçlerinin etkileri yalnızca Mezopotamya bölgesiyle sınırlı kalmamış aynı zamanda Anadolu'da ve Suriye-Filistin bölgesinde de kendisini hissettirmişti. Babil çivi yazısının MÖ 1. yüzyıldan sonra çok büyük oranda kullanım dışı kalmasıyla (şeyleri kayıt altına almadaki görünür ve örtük gücünün yitirilmesi) birlikte artık bir Babil düşünce ve kavrama modelinin izi sürülememiştir. Bu durum Babil epistemolojisinin çok büyük oranda yazıya bağımlı olduğunu ve dinamizmini yazıyla birlikte muhafaza ettiğini göstermesi açısından oldukça önemli bir göstergedir. İkincisi ise (9. bölüm) Babil epistemolojisi ile çivi yazısı arasındaki sıkı ilişkinin bir değerlendirmesini içerir. Bu bölüm aynı zamanda bütün kitabın adeta kısa bir özetini sunmaktadir.

Mieroop'un son bölümdeki genel değerlendirmeleri bu yazının da sonuç bölümünü oluşturabilir. Kitabın bütün iddiası "Babillilerin bir göstergebilimden ziyade bir yaz̧bilimine (gramatoloji) ibtiyaç duyduklar" üzerinedir. Zira çivi yazısı işaret sayısının fazlalığı ve çeşitliliği nedeniyle çok anlamlılığa oldukça müsaitti. Mezopotamyalılar çok sayıda listeler oluşturdular. Çünkü şeyleri listelemenin bilgiyi anlamadaki ve kavramadaki rollerini gördüler. Sözcük listeleri, kehanet serileri ve yasa maddelerindeki ifadeler ya da maddeler ancak söz konusu serilerdeki diğer içeriklerle birlikte ele alındı̆̆ında bir anlam ifade edebilmekteydi. Babilli bilginler ve uzmanlaşmış okuryazarlar bu metinlerde yazılı bir dünyanın gerçeklikleriyle ilgilendiler. Muhtemel olanın egzersiziydi bu. Bu, bir yaşama-eyleme geçme tarzıyla değil de bir bilme biçimiyle ilgilenen spekülatif bir akıl yürütme biçimiydi. Ancak yazılı bilgi üzerine düşünmek bütünüyle dış dünyayı göz ardı etmek anlamına da gelmezdi. Bilgi üretimi ile gözlem arasında ilişki listelerde oluşturulan yazılı gerçekliğin dış dünyadaki sınanması şeklinde olurdu: önce şeyler gözlemlenip sonuçlar kayda geçirilmemiş, kayda geçirilenler sonrasinda gözlemlenmeye çalışılmıştır. Kehanet serilerinde bu durum çok açık bir şekilde görülebilmekteydi. $\mathrm{Bu}$ durum olasilıkların fiziksel potansiyellerini görmek istemenin tamamen dişlanmadığının göstergesiydi. Sonuç olarak "yažlı bir dünyayı çalısmak hayal edilemeyen alanlar açı̆a çıkarmaya olanak sağlaması bakımından” Babil epistemolojisinin temelini oluşturmaktayd1 (ss. 219-224).

\section{Sonuç Değerlendirmesi}

Sonuç olarak Mieroop'un bu kitabı felsefenin (felsefi düşüncenin/felsefe geleneğinin) antik Yunanlardan önce var olduğunu kanıtlamaya çalışma çabasının yanı sıra belki de daha ziyade Babillilerin ya da Eski Mezopotamyalıların felsefe, mantık, bilim veya ilim adına ne dersek diyelim şeyler üzerine akıl yürütme çabalarının kendilerine has biçimlerini göstermeyi amaçlar. Her antik kültürde olduğu gibi Eski Mezopotamyalılar da evrene, yaşama ve şeylere dair metafizik bilinmezliklere ilgi duymuşlar ve soyut alanın bilgisini merak etmişlerdir. Onlar, insanın var olma amacina ve onun doğasına has olan bazı evrensel olguları, bunları 


\section{Gökhan Kağnucı}

kavramlaştırmadan (buna gerek duymadan ya da modern bir kavramlaştırma biçiminden farklı bir yolla) ve sistematik bir kategorizeyle sinırlandırmadan soruşturabilmenin mümkün olabileceğini düşünmüsslerdir. ${ }^{14}$ Mieroop, sözcük listeleri, kehanet serileri ve yasa maddeleri temelinde bir Babil felsefi düşüncesinin ya da epistemolojisinin varlı̆̆ını terminolojik bariyerleri (örneğin çivi yazılı dillerde "felsefe" anlamına gelen herhangi bir kavram-terim yoktur) aşmaya çalışarak tartışır. Vardığ1 sonuç, her ne kadar klasik Batı düşünce yapısına, kavram hiyerarşisine ya da bilimsel önyargılara ters düşerse düşsün, Mezopotamyalılanın entelektüel bilgi üretiminin, aktarımının, temsilinin, yorum bilgisinin ve muhafazasinın uzun bir geleneğin önemli bir pratiği ve parçası olduğudur. Onların tüm bu ilmi faaliyetleri birçok hususun yanı sıra şeylere dair hiçbir zaman sona ermeyecek kendilerine özgü kavramsal bir mahiyetin eşlik ettiği dinamik bir akıl yürütme biçiminin etkin olduğu bir anlam arayışıyla ilgiliydi. Belki de soruyu "Eski Mezopotamyalılarda felsefe var miydı?" yerine, "Mezopotamyalılara göre felsefe neydi?" şeklinde sormak, binlerce y1l devam eden yazılı bir geleneğin düşünceyle ilişkisinin derinliğini daha oturaklı anlamak açısından daha yerinde olabilecektir.

\section{Kaynaklar}

Crisostomo, Jay, "Language, Translation, and Commentary in Cuneiform Scribal Practice", Journal of Ancient Near Eastern History 5/1-2, 2018, 42-56.

De Boer, Rients, "Mieroop, M. Van De- Philosophy Before the Greeks: The Pursuit of Truth in Ancient Babylonia", Bibliotheca Orientalis LXXIV/5-6, 2017, 600-602.

Derrida, Jacques, Gramatoji, (Çeviren: İsmet Birkan), Ankara: Bilgesu Yayıncılık, 2011.

Fazlığlu, İhsan, “Greklerden Önce Felsefe: Kadim Babil'de Hakikat Arayışı", Arka Kapak Dergisi 18, 2017, 16.

Frahm Eckart, "The Perils of Omnisignificance: Language and Reason in Mesopotamian Hermeneutics", Journal of Ancient Near Eastern History 5/1-2, 2018, 1-23.

Gadamer, Hans-Georg, Hakikat ve Yöntem, (Çevirenler: Hüsamettin Arslan-İsmail Yavuzcan), Cilt I, İstanbul: Paradigma Yayınları, 2008.

Piccin, Michela, "Van De Mieroop (M.). Babylonian Philosophy: Philosophy Before the Greeks: The Pursuit of Truth in Ancient Babylonia", The Classical Review 69/2, 2019, 612-614.

Scurlock, JoAnn, Sourcebook for Ancient Mesopotamian Medicine, Atlanta: SBL Press, 2014.

Van De Mieroop, Marc, King Hammurabi of Babylon: A Biography, Blackwell: Oxford, 2005.

Van De Mieroop, Marc, Philosophy Before the Greeks: The Pursuit of Truth in Ancient Babylonia, Princeton: Princeton University Press, 2016.

14 Michela Piccin, "Van De Mieroop (M.). Babylonian Philosophy: Philosophy Before the Greeks: The Pursuit of Truth in Ancient Babylonia", The Classical Review 69/2, 2019, s. 614; Rients de Boer, "Mieroop, M. Van De- Philosophy Before the Greeks: The Pursuit of Truth in Ancient Babylonia", Bibliotheca Orientalis LXXIV/5-6, 2017, s. 602. 
Van De Mieroop, Marc, “Theses on Babylonian Philosophy”, Journal of Ancient Near Eastern History 5/1-2, 2018, 15-39.

Van De Mieroop, Marc, "Babil Felsefesi Üzerine Tezler", (Çeviren: Gökhan Kağnıc1), Cihannüma: Tarih ve Coğrafya Arasturmalar Dergisi VI/2, 2020, 231-258.

Y1lmaz, Merve Nur, "Marc Van De Mieroop. Babylonian Philosophy: Philosophy Before the Greeks: The Pursuit of Truth in Ancient Babylonia", Divan: Disiplinlerarası Calısmalar Dergisi 23/44, 2018-1, 169-174.

Gökhan Kağnıc1*

* Dr. Öğr. Üyesi, İzmir Kâtip Celebi Üniversitesi, Sosyal ve Beşerî Bilimler Fakültesi, Tarih Bölümü, 35620, Balatçı, Çiğli-İzmir/Türkiye, gokhan.kagnici@ikc.edu.tr, Orcid ID: 0000-0002-8357-6624 